\title{
ANALYSIS OF DIETARY PATTERNS AND BODY COMPOSITION PARAMETERS IN THE POLISH POPULATION
}

\author{
Małgorzata Kostecka ${ }^{1}$, Monika Bojanowska ${ }^{I}$, Julianna Kostecka ${ }^{2}$, Anna Ciołek ${ }^{1}$ \\ ${ }^{1}$ University of Life Science, Faculty of Food Science and Biotechnology, \\ Department of Chemistry, Akademicka street 15, 20-950, Lublin, Poland \\ ${ }^{2}$ Medical University of Lublin, Faculty of Medicine, Chodźki street 19, 20-093 Lublin, Poland
}

\begin{abstract}
Background. Lifestyle factors are the key determinants of health. Diet exerts the great influence on the weight to height ratio and the body fat percentage. In addition to total energy intake, the type and quality of the diet can also play a role in the etiology of obesity in susceptible individuals.

Objective. Aim of this study was to identify the dietary patterns of the Polish population and to determine the associations between these characteristics and body composition parameters. This study presents the clustering of dietary models and body composition to determine the association of these dietary patterns with BMI, physique rating (body type) or visceral fat.

Material and methods. The sample consisted of 402 respondents aged 18 to 65 . Nutrition models were identified with cluster analysis. Logistic regression modelling with adjustment for confounders was applied. Three dietary-lifestyle patterns were identified.

Results. Individuals belonging to the processed food model were at significantly higher risk of overweight and obesity expressed by BMI scores (OR=1.55; 95\%CI: 1.26-1.89). The average BMI score was $28.19 \pm 3.45 \mathrm{~kg} / \mathrm{m} 2$ in the processed food model, $23.78 \pm 2.21 \mathrm{~kg} / \mathrm{m} 2$ in the control group, and $22.17 \pm 2.69 \mathrm{~kg} / \mathrm{m} 2$ in the healthy nutrition model. Respondents belonging to the processed food model were also characterized by considerably higher body fat percentage $(\mathrm{OR}=1.89$, 95\%CI: 1.37-2.34) and higher visceral fat levels (OR=2.12; 95\%CI: $1.42-2.34)$. Frequent intake (at least several times a week) of sweetened carbonated or non-carbonated beverages $(\mathrm{p}=0.002)$ and instant foods $(\mathrm{p}=0.006)$ were the main factors associated with the risk of higher body fat percentage and higher visceral fat levels.

Conclusions. Dietary patterns have been proposed as a solution to investigating the association between food choice and body composition, and such studies focus on analyses of the entire diet, rather than on the intake of individual nutrients or food groups.
\end{abstract}

Keywords: dietary patterns, cluster analysis, body composition, BMI, body mass index, visceral fat level

\section{STRESZCZENIE}

Wprowadzenie. Czynniki związane ze stylem życia mają kluczowe znaczenie dla zdrowia. Dieta wpływa na masę ciała, a także na wartość BMI i procent tkanki tłuszczowej. Oprócz całkowitego spożycia energii, rodzaj i jakość diety może również odgrywać rolę w etiologii otyłości.

Cel. Celem pracy była identyfikacja wzorców i profili żywieniowych polskiej populacji oraz określenie związków między tymi cechami a parametrami składu ciała. Badanie przedstawia poszukiwanie związku wzorców żywieniowych z BMI, oceną budowy ciała (typem ciała) lub trzewną tkanką tłuszczową.

Materiał i metody. Próba składała się z 402 respondentów w wieku od 18 do 65 lat. Modele żywienia zidentyfikowano za pomocą analizy skupień. Zastosowano modelowanie regresji logistycznej z dostosowaniem do czynników zakłócających. Zidentyfikowano trzy wzorce żywieniowe i stylu życia.

Wyniki. Osoby należące do modelu żywności przetworzonej miały istotnie wyższe ryzyko nadwagi i otyłości wyrażone

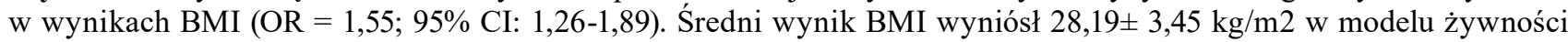

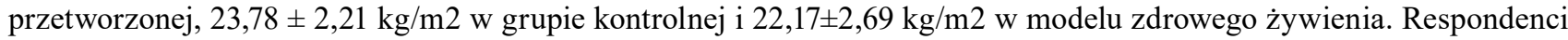
należący do modelu żywności przetworzonej charakteryzowali się również znacznie wyższym procentem tkanki tłuszczowej $(\mathrm{OR}=1,89 ; 95 \% \mathrm{CI}: 1,37-2,34)$ oraz wyższym poziomem trzewnej tkanki tłuszczowej $(\mathrm{OR}=2,12 ; 95 \% \mathrm{CI}$ : 1,42-2,34). Częste spożywanie (co najmniej kilka razy w tygodniu) słodzonych napojów gazowanych lub niegazowanych $(\mathrm{p}=0,002)$ oraz produktów instant $(\mathrm{p}=0,006)$ było głównymi czynnikami związanymi z ryzykiem zwiększonej zawartości tłuszczu w organizmie i wyższego poziomu tłuszczu trzewnego.

Corresponding author: Kostecka Małgorzata, University of Life Science, Faculty of Food Science and Biotechnology, Department of Chemistry, Akademicka street 15, 20-950, Lublin, Poland, phone number: +48 8144568 46; e-mail: kostecka.malgorzatam@gmail.com

(C) Copyright by the National Institute of Public Health - National Institute of Hygiene 
Wnioski. Wzorce żywieniowe zostały zaproponowane jako rozwiązanie do badania związku między sposobem żywienia i wyborem żywności a składem ciała.

Słowa kluczowe: wzorce żywieniowe, analiza skupień, skład ciała, BMI, poziom tłuszczu trzewnego

\section{INTRODUCTION}

Lifestyle factors are the key modifiable determinants of health. Diet exerts the great influence on the weight to height ratio and the body fat percentage. In addition to total energy intake, the type and quality of the diet can also play a role in the etiology of obesity in susceptible individuals. High-fat diets can lead to excessive calorie intake, and they can induce metabolic changes that promote the deposition of adipose tissue [2,15]. An individual's lifestyle changes in various stages of life, and eating habits can play a positive or a negative role in ageing processes and the functioning of bodily tissues, organs and the entire body. Excessive body weight has been associated with various chronic diseases, including cardiovascular disease, diabetes, many forms of cancer and numerous musculoskeletal problems [13]. Overweight and obesity can increase the risk of many health problems, including diabetes, heart disease, and certain cancers [38]. The regional distribution of body fat may be of greater consequence than overall body fat. Excess visceral fat in the abdominal cavity is associated with a higher risk of multiple metabolic complications, chronic diseases and mortality [9, 20, 21, 31]. Dietary guidelines provide evidence-based information on food choices to reduce the risk of chronic diseases, such as obesity. The assessment of eating habits based on dietary patterns emerged as an alternative method in nutritional epidemiology research, and it is justified by the fact that people do not eat certain foods or nutrients in isolation, but rather in combination during meals. Food products contain various combinations of nutrients and other compounds that deliver synergistic effects. The aim of research studies investigating dietary patterns is to identify food combinations that offer the greatest health benefits or are deleterious to health $[12,27]$. The relevant studies search for the associations between dietary patterns and the risk of developing diet-related diseases. Haq et al. [14] analyzed the body composition, dietary patterns and the associated factors in students of the Nanjing Medical University in China. Egg et al. [8] searched for possible correlations between three dietary patterns and the risk of overweight/obesity and higher body fat percentage. A study conducted in New Zealand demonstrated that analyses of dietary patterns are a useful tool for assessing the links between diet and metabolic health [17]. Dietary patterns have not been studied extensively in Polish adults to date.
Therefore, the aim of this study was to identify the dietary patterns and nutrient profiles of the Polish population and to determine the associations between these characteristics and body composition parameters which are regarded as significant risk factors for lifestyle diseases.

\section{MATERIAL AND METHODS}

\section{Study design and participants}

The study was performed on 402 respondents aged 18 to 65 . The subjects were the patients of outpatient clinics (where general medical practice is run by general practitioners and where the invitation to participate in the study was posted) and a nutrition clinic of the Lublin University of Life Sciences, as well as university students residing in dormitories in the Polish voivodeships of Świętokrzyskie and Lubelskie. The study was conducted between 22 February and 31 June 2019. The inclusion criteria were: minimum 18 years of age, good overall health (absence of chronic diseases and diet-dependent diseases that require specialist treatment or an elimination diet), consent to participate in a body composition analysis and complete a questionnaire. The exclusion criteria were as follows: epilepsy, implanted pacemaker, pregnancy. All participants signed written informed consent forms to participate in the research. The study was conducted in two stages.

In the first stage, the participants filled out a questionnaire and received instructions on how to prepare for a bioelectrical impedance analysis (BIA). The respondents completed a printed questionnaire without assistance. The mean completion time was 34 \pm 11 minutes. Each of the participants was informed with the measurement procedure, explained the possible risks. To prepare for the BIA, the participants were asked to:

- refrain from consuming alcohol and caffeine for 24 hours before the exam,

- avoid strenuous physical exercise for 12 hours before the exam,

- consume the last meal of the day not later than 4-6 hours before the exam

In the second stage of the study, the participants underwent a BIA on the agreed date to ensure that the above requirements were met (Figure 1).

\section{Body composition analysis}

The body composition analysis was conducted with the Tanita BC-545n segmental body composition 


\section{8 persons were invited to participate in the} study

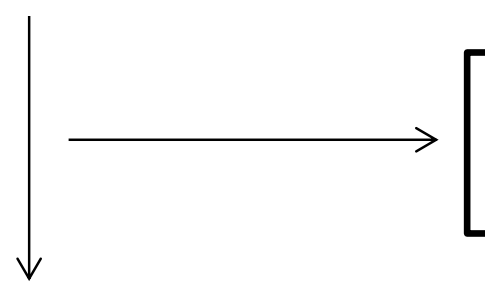

164 participants did not complete the entire questionnaire and were excluded from the study

614 participants completed the entire questionnaire

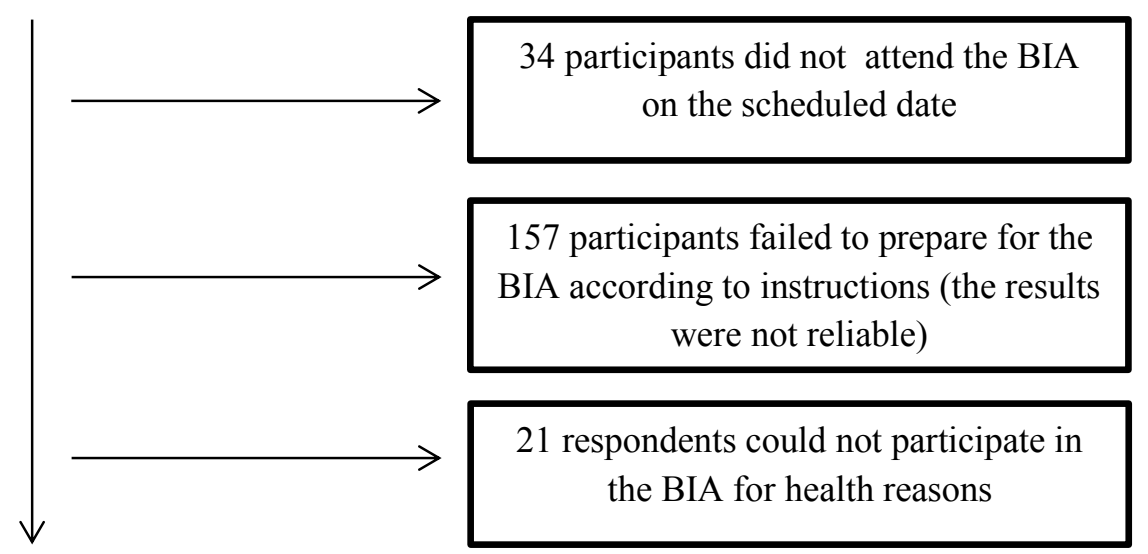

Total sample, $n=402$, respondents correctly completed the questionnaire and participated in the BIA

Figure 1. Sample collection

monitor which measures 10 parameters. The monitor has 8 electrode sensors ( 4 sensors in the foot platform and 4 sensors in hand-held grips), and it measures body fat percentage and muscle mass in each body segment (right and left hand, right and left leg, trunk area). The monitor relies on the BIA technology which is deployed in professional Tanita equipment.

Tanita BC-545N measures the following body parameters: body mass (in $\mathrm{kg}$ ), body fat (percentage), muscle mass (in $\mathrm{kg}$ ), total body water (in \%), physique rating (body type), visceral fat, Body Mass Index $\left(\mathrm{kg} / \mathrm{m}^{2}\right)$, basal metabolic rate.

The measurements are performed with an accuracy of: body mass: $100 \mathrm{~g}$, body fat percentage: $0.1 \%$, muscle mass: $100 \mathrm{~g}$ and total body water: $0.1 \%$.

The measurements of body weight $(\mathrm{kg})$ and height (cm) were taken according to International Standards for Anthropometric Assessment (2001), all recoded with a precision of $0.1 \mathrm{~kg}$ or $0.1 \mathrm{~cm}$, respectively. All measurements were taken in light clothing and without shoes.

\section{Evaluation of eating habits}

The dietary patterns and eating habits of the respondents were evaluated with the Dietary Habits and Nutrition Beliefs (KomPAN) questionnaire for participants aged 16 to 65 . The questionnaire is an extended version of the Eating Behavior Questionnaire (EBQ), and it was developed in 2014 by the Dietary Behavior Team of the Committee of Human Nutrition Science of the Polish Academy of Sciences [10]. The questionnaire is composed of three parts and 45 validated questions. The first part explores the respondents' eating habits; the second part investigates meal frequency; and the third part contains questions about the respondents' lifestyle and physical activity levels.

The answers to the first two parts were used to identify three nutrition models. Based on a review of the literature [35-37], two indicators were proposed for assessing the quality of the respondents' diets. The first indicator groups foods that deliver potential 
health benefits, and the second indicators accounts for unhealthy foods:

- Pro-Healthy-Diet-Index-10 (pHDI-10)

- Non-Healthy-Diet-Index-14 (nHDI-14)

The indicators were calculated by summing the consumption frequencies (times/day) of foods items in pHDI-10 and nHDI-14 groups (Table 1, Table 2).

The consumption frequencies (times/day) of foods from both groups were summed up and expressed on a scale of 0 to 100 points to facilitate the interpretation of the results:

\begin{tabular}{|c|c|c|}
\hline $\begin{array}{c}\text { Consumption } \\
\text { frequency }\end{array}$ & $\begin{array}{c}\text { pHDI-10 } \\
\text { healthy nutrition } \\
\text { model }\end{array}$ & $\begin{array}{c}\text { nHDI-14 } \\
\text { processed food } \\
\text { model }\end{array}$ \\
\hline Low & $0-33$ & $0-33$ \\
\hline Moderate & $34-66$ & $34-66$ \\
\hline High & $67-100$ & $67-100$ \\
\hline
\end{tabular}

Potential relationships were also identified between the frequency of consuming specific food products (evaluated in part B of the KomPAN questionnaire), BMI and body composition.

\section{Statistical analysis}

Categorical variables were presented as a sample percentage (\%) and continuous variables as medians with a interquartile range. The differences between groups were verified with a $C h i^{2}$ test (categorical variables) or a Mann-Whitney test (continuous variables). Before statistical analysis, the normality of the distribution of the variables was checked with a Kolmogorov-Smirnov test.

Logistic regression modelling was applied to assess the adherence to chosen DP by summing the consumption frequencies (times/day) of foods items in pHDI-10 and nHDI-14 groups in respect to referent DP (control group).

Table 1. Food items with potential health benefits (pHDI-10) listed in the KomPAN questionnaire

\begin{tabular}{|l|}
\hline Whole-grain bread \\
\hline Barley groats, oat flakes, whole-grain pasta and other coarse grits \\
\hline Milk (including flavored milk, hot or cold chocolate, milk-based coffee) \\
\hline Fermented dairy beverages, including yogurt and kefir (plain or flavored) \\
\hline Tvorog cheese (including cream cheese and tvorog-based desserts) \\
\hline White meat, including chicken, turkey and rabbit \\
\hline Fish \\
\hline Legumes, including beans, peas, soybeans and lentils \\
\hline Fruit \\
\hline Vegetables \\
\hline pHDI-10 = total consumption frequency of $\mathbf{1 0}$ food groups (times/day; range: $\mathbf{0 - 2 0})$ \\
\hline
\end{tabular}

Table 2. Unhealthy food items (nHDI-14) listed in the KomPAN questionnaire

\begin{tabular}{|l|}
\hline White bread, including wheat bread, rye bread, mixed wheat-rye bread, toast bread, baguettes, rolls \\
\hline White rice, pasta and fine grits such as semolina and couscous \\
\hline Fast food, such as French fries, hamburgers, pizza, hot dogs, melted cheese sandwiches \\
\hline Fried meat and fried flour-based products \\
\hline Butter for spreading, frying and roasting. \\
\hline Lard for spreading, frying and roasting \\
\hline Ripened cheese, including processed cheese and blue cheese \\
\hline Processed meats, including cold cuts and sausages \\
\hline Red meat, including pork, beef, veal, mutton, lamb and venison \\
\hline Sweets, including candy, biscuits, cakes, chocolate and muesli bars \\
\hline Canned meats \\
\hline Sweetened carbonated beverages such as Coca-Cola, Pepsi, Sprite, Fanta, orange soda, lemonade \\
\hline Energy drinks \\
\hline Alcoholic beverages \\
\hline nHDI-14 = total consumption frequency of $\mathbf{1 4}$ food groups (times/day; range: 0-28) \\
\hline
\end{tabular}


The odds ratios (ORs) and $95 \%$ confidence intervals (95\% CIs) were calculated. Crude and adjusted models were created. The significance of ORs was assessed by Wald's statistics. The levels of statistical significance were set at $\mathrm{P}<0.05\left(^{*}\right), \mathrm{P}<0.01(* *), \mathrm{P}<0.001\left(^{(* *}\right)$. Analyses were performed using Statistica software (version 13.1 PL; StatSoft Inc., Tulsa, OK, USA; StatSoft, Krakow, Poland).

\section{RESULTS}

\section{Association between Body Composition and Eating Habits}

Both minimum and maximum height and body mass were higher in male than in female subjects $(\mathrm{p}=0.002)$. Male respondents were also characterized by a higher BMI. Body fat percentage was minimum $27 \%$ in $50 \%$ of the female subjects, and it ranged from $13.1 \%$ to $16.2 \%$ in every other male participant. Both minimum and maximum body fat percentage was lower in men, whereas women were characterized by significantly lower $(p=0.001)$ visceral fat levels. Muscle mass and bone mass were higher in male subjects. Women were characterized by greater variations in body composition parameters. The descriptive statistics for the body composition analysis are presented in Table 3 .

The evaluated population involved both underweight subjects and individuals with excessive body mass and BMI higher than 30 (average BMI: $23 \pm 4 \mathrm{~kg} / \mathrm{m}^{2}$ ). Healthy BMI values were noted in half of the studied population. Overweight and obesity were more prevalent in women aged 40-59 $(\mathrm{p}=0.001)$ and men aged 18-39 $(\mathrm{p}=0.006)$. BMI values were inversely proportional to the number of consumed meals $(p=0.003)$ and directly proportional to the frequency of snacking between meals $(\mathrm{p}=0.001)$. The consumption of sweetened beverages and dairy desserts (cream cheese, sweetened dairy beverages and sweet snacks) daily or several times a day was significantly higher $(\mathrm{p}=0.002)$ in patients with a BMI of $25-30 \mathrm{~kg} / \mathrm{m}^{2}$, whereas the consumption of salty snacks, cakes, fruit juice and sweetened carbonated beverages more frequently than several times a week was significantly higher $(\mathrm{p}=0.001)$ in individuals with a BMI higher than $30 \mathrm{~kg} / \mathrm{m}^{2}$. Considerable variations in body fat percentage were observed in the studied population. Individuals with very low body fat percentage accounted for $11.6 \%$ of the surveyed men aged $18-39$, whereas in $34.9 \%$ of the surveyed women aged 40-59, body fat levels were three times higher. The average body fat percentage in the analyzed population was similar to that reported by Elffers et al. [9].

Total body water was generally low in the studied population, and this parameter was differentiated by sex (Figure 2). Age was less negatively correlated with low total body water in men $(\mathrm{p}=0.001)$. The results were correlated with low or very low fluid intake




levels declared in the KomPAN questionnaire. Women were more likely to consume sweetened hot beverages (several times a day vs. several times a week, $p=0.001$ ) and vegetable juice (several times a week vs. 1-3 times a month, $\mathrm{p}=0.003$ ) than men. The consumption of sweetened carbonated beverages was similar in both sexes, but differences were noted between age groups. Younger subjects (18-39) consumed carbonated beverages once a day or more frequently than respondents from the remaining age groups $(p=0.003)$ who consumed carbonated drinks 1-3 times a month. Low fluid intake was also correlated with low water intake which ranged from several times a week to once a day. Water was most frequently consumed by young women with a BMI of up to $23.5(\mathrm{p}<0.05)$.

The studied population included individuals with minimum healthy BMI scores and excessive body fat percentage relative to muscle mass (hidden obesity), as well as individuals with maximum healthy BMI scores, and excessive body fat percentage and muscle

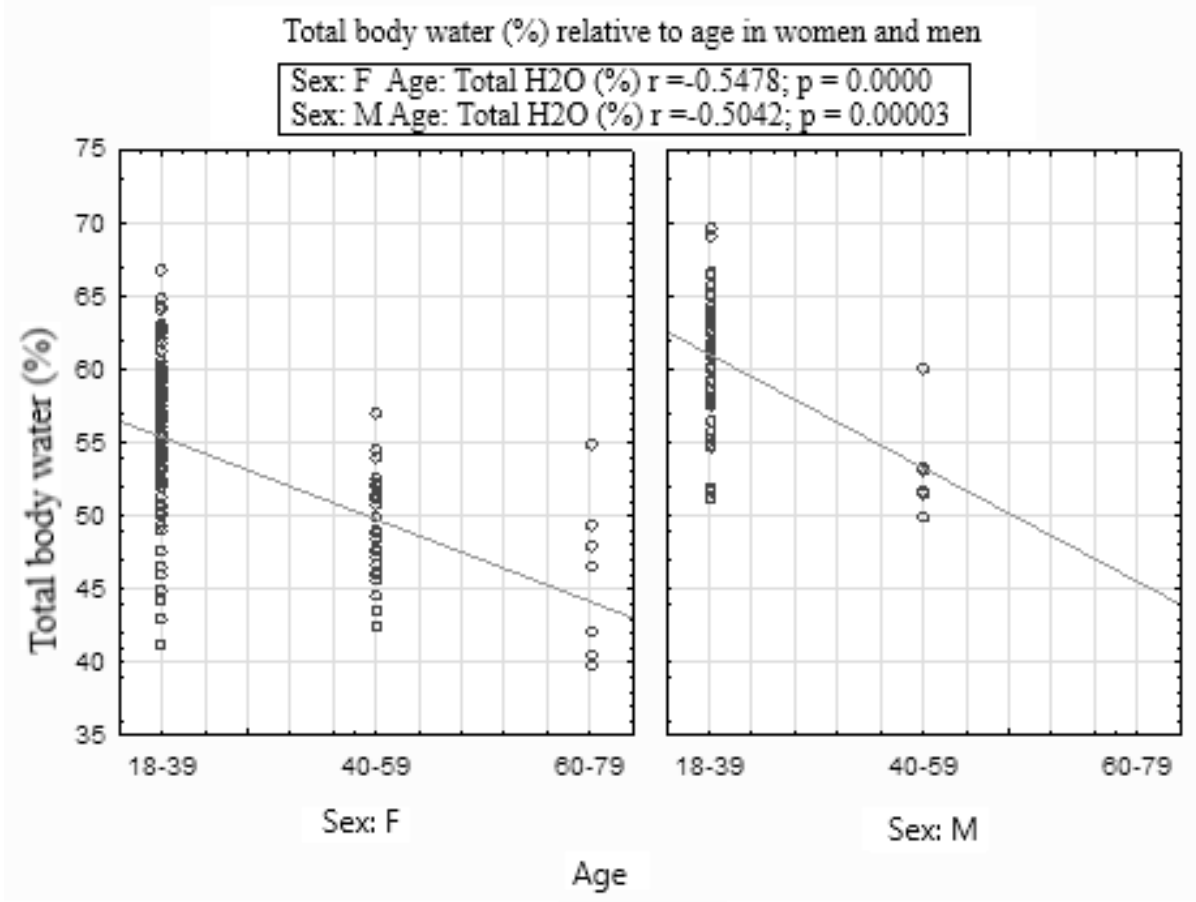

Figure 2. Scatter plot of the relationship between total body water (\%) and age in women and men

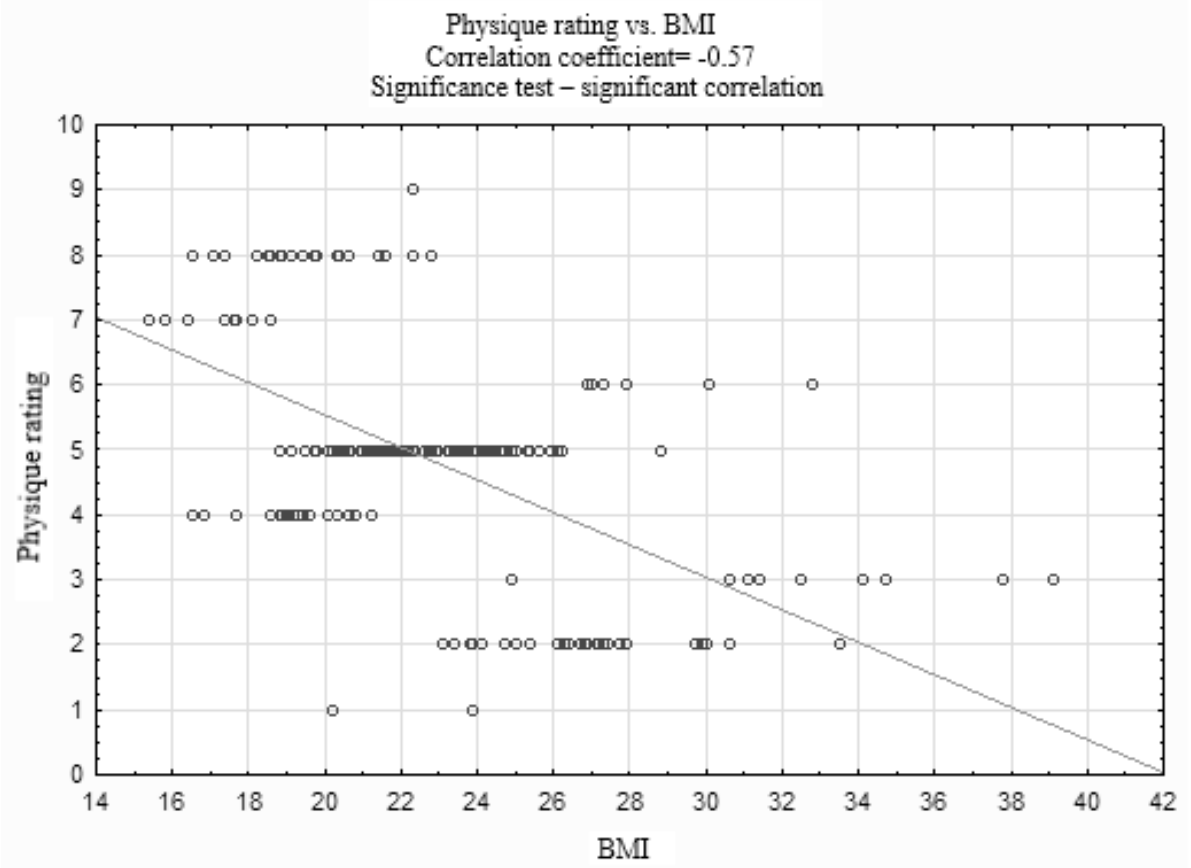

Figure 3. Scatter plot of the relationship between BMI values and physique rating 
mass (Figure 3). The studied population included individuals with bone mass both below and above the recommended values.

Physical activity was not correlated with physique rating. Higher levels of physical activity were not always correlated with lower BMI scores. The statistical analysis did not reveal correlations between higher levels of physical activity and BMI scores in the range of $21-25 \mathrm{~kg} / \mathrm{m}^{2}$. The only exception was noted in the group of women aged 18-39, where physical activity undertaken more than 4-5 times a week was correlated with lower BMI scores (21.7 vs. $22.1 \mathrm{~kg} / \mathrm{m}^{2}$ in the overall female population) than in women from other age groups who performed physical exercise several times a week (average BMI of $22.9 \mathrm{~kg} / \mathrm{m}^{2}$ ).

A strong positive correlation was observed between BMI ( $p=0.007)$ (Figure.4). An increase in body mass was accompanied by a rise in metabolic rate, and sex was not a differentiating factor. An increase in the respondents' chronological age was accompanied by a rise in metabolic age $(\mathrm{p}=0.001)$.

Visceral fat was correlated with the respondents' BMI scores (Figure.5). Visceral fat was most highly correlated with BMI scores in men aged 40-59 (average of 10.3, $\mathrm{p}=0.001$ ) and women aged 40-59 (average of 9.6, $\mathrm{p}=0.007)$. An analysis of the respondents' eating

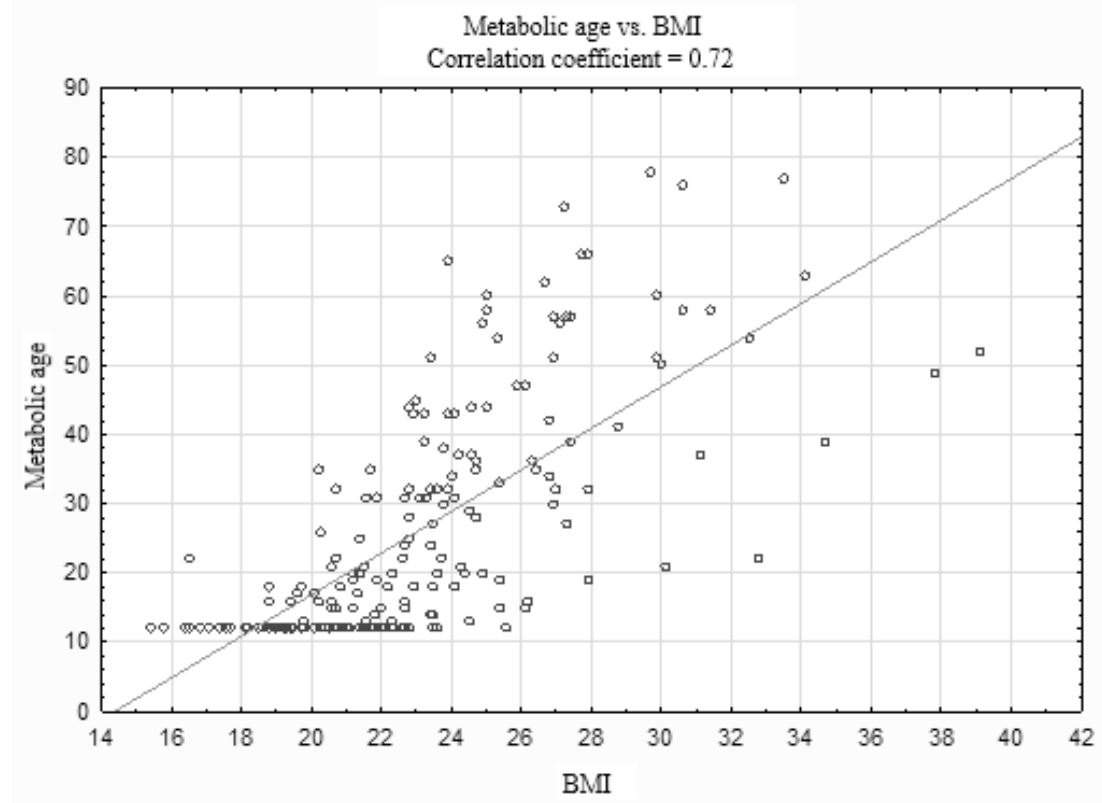

Figure 4. Scatter plot of the relationship between metabolic age and BMI

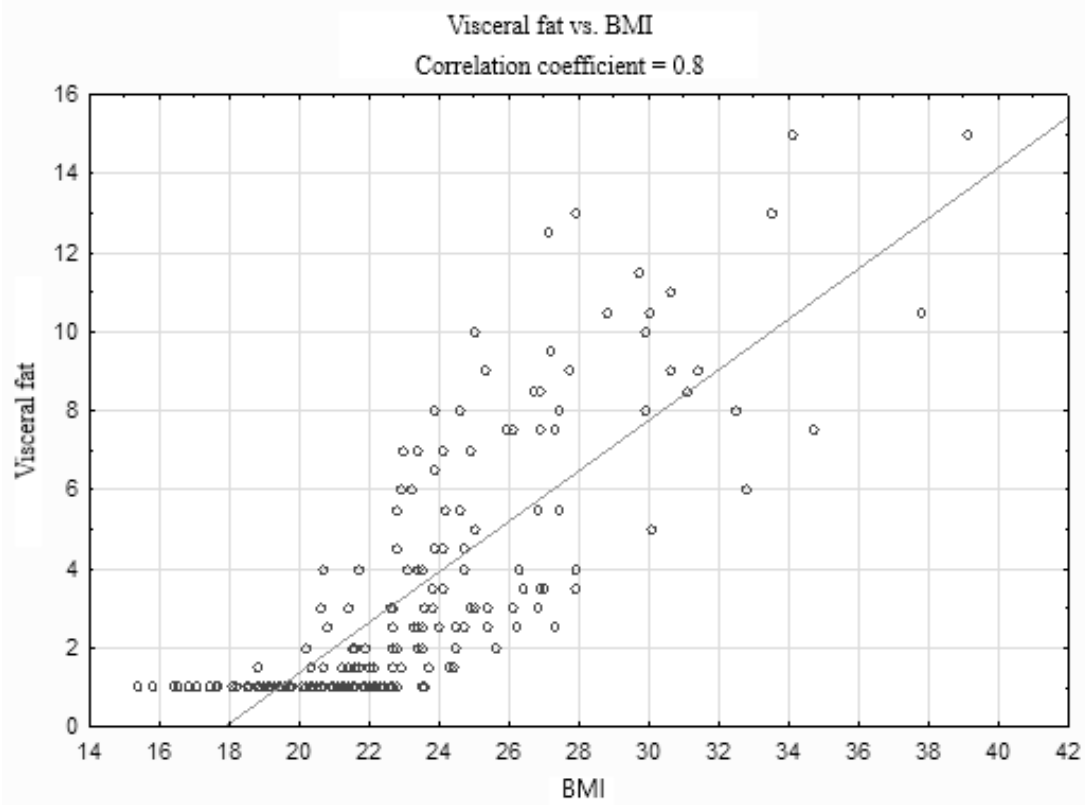

Figure 5. Scatter plot of the relationship between visceral fat and BMI 
habits revealed that higher visceral fat was correlated with the consumption of ready-made meals and highly processed foods at least several times a week $(\mathrm{p}=0.001)$, sweets and sweet snacks once a day $(\mathrm{p}=0.003)$, and sweetened beverages several times a week $(\mathrm{p}=0.001)$. Male subjects aged 40-59 who consumed a large women aged 18-39 who consumed whole-grain products once a day / several times a day $(\mathrm{p}=0.002)$.

Association between Nutrition Models and Body Composition Parameters

The results of the questionnaire survey were used to identify three nutrition models (Table 4):

Table 4. Odds ratio (95\% confidence interval) of body composition parameters in the identified nutrition models

\begin{tabular}{|c|c|c|}
\hline Parameters & $\begin{array}{c}\text { Processed food model } \\
\text { (vs. control group) }\end{array}$ & $\begin{array}{c}\text { Healthy nutrition model } \\
\text { (vs. control group) }\end{array}$ \\
\hline BMI & $1.55(1.26-1.89)^{*}$ & $1.11(0.79-1.28)$ \\
\hline Body fat $\%$ & $1.89(1.37-2.34)^{* *}$ & $0.76(0.34-1.01)^{*}$ \\
\hline Total body water $\%$ & $1.27(0.84-1.51)$ & $1.21(0.87-1.54)$ \\
\hline Muscle mass & $1.12(0.78-1.32)$ & $1.19(1.03-1.31)$ \\
\hline Visceral fat & $2.12(1.42-2.34)^{* * *}$ & $0.67(0.31-0.89)^{* *}$ \\
\hline
\end{tabular}

Overweight/obesity and normal weight identified as BMI-for-age categorized with sex-specific cut-offs according to: overweight $\mathrm{BMI} \geq 25 \mathrm{~kg} / \mathrm{m}^{2}$, normal weight $\mathrm{BMI}=18.5$ to $24.9 \mathrm{~kg} / \mathrm{m}^{2}$;

Statistically significant: $* p<0.05 ; * * \mathrm{p}<0.01, * * * \mathrm{p}<0.001$

meal less than one hour before going to bed were characterized by higher visceral fat than men who ate the last large meal not later than two hours before going to bed $(\mathrm{p}=0.004)$.

Meal frequency was not correlated with body fat percentage (age 18-39: $p=0.5421$; age 40-59: $p=0.5441$; age 60-79: $p=0.411)$. Body fat percentage was influenced by fat intake. The consumption of fats (oil, butter, margarine, other fats) was not correlated with body fat percentage $(p=0.616)$ in the youngest respondents, but it was associated with higher body fat levels in subjects aged 40-59 ( $\mathrm{p}=0.002)$ who consumed fats once daily / several times a day. Another analyzed dietary factor was the consumption of sweets and sweet snacks. In the studied population, the consumption frequency of sweets and sweet snacks (never $\rightarrow$ several times a day) was not correlated with body fat percentage. However, body fat levels were significantly higher $(\mathrm{p}=0.006)$ in men who ate sweets and sweet snacks several times a week / once a day.

In the studied population, alcohol consumption was not correlated with body fat percentage. The only exception were women aged 18-39, where higher frequency of alcohol consumption was accompanied by a decrease in visceral fat $(\mathrm{p}=0.023)$.

The influence of health-promoting food products was also analyzed. The proportions of fruit and vegetables in the diet did not affect body fat levels regardless of the respondents' sex and age. However, women aged 30-59 who consumed fruit and vegetables once a day / several times a day were characterized by significantly lower visceral fat $(p=0.001)$ and significantly lower BMI scores $\left(21.4 \mathrm{~kg} / \mathrm{m}^{2}\right)$ relative to the overall female population $\left(22.1 \mathrm{~kg} / \mathrm{m}^{2}\right)(\mathrm{p}=0.001)$.

The consumption of whole-grain products did not affect the analyzed body composition parameters. Lower body fat percentage was observed only in
1. Processed food model (subjects who consumed white bread, ready-made meals, instant foods, fast foods, red meat, oil, sweets and sweet snacks, sweetened beverages and energy drinks more often than several times a week; respondents who consumed whole-grain bread, milk and fermented dairy beverages, vegetables, fruit, legumes and fish less than several times a week). This nutrition model was correlated with younger age $(p=0.0032)$ and occupational status: university students $(p=0.004)$. The respondents' place of residence and sex were not the differentiating factors.

2. Healthy nutrition model (respondents who consumed whole-grain products, vegetables, fruit, legumes, milk and fermented dairy beverages more than once a day; respondents who consumed white bread, ready-made meals, instant foods, fast foods, red meat, oil, sweets and sweet snacks, sweetened beverages and energy drinks less than several times a month). This nutrition model was correlated with the place of residence in cities with a population higher than $100,000(p=0.001)$ and occupational status: employed ( $\mathrm{p}=0.003)$. The respondents' sex and age were not the differentiating factors.

3. Optimal nutrition model (respondents who consumed ready-made meals, instant foods, fast foods, sweet and salty snacks several times a month; respondents who consumed whole-grain products, vegetables, fruit, fish, legumes, milk and fermented dairy beverages at least several times a week) which was regarded as the control group. This nutrition model was correlated only with sex, and women adhered to the optimal model significantly more frequently than men $(p=0.002)$. 


\section{DISCUSSION}

This study investigated the relationships between dietary patterns and body composition parameters which play an important role in evaluations of health and the risk of diet-dependent diseases. The aim of many research studies is to develop a quick screening test based on analyses of body composition parameters, body mass, BMI score and body fat percentage [19, $22,32,33]$. Dietary patterns have been proposed as a solution to investigating the association between food choice and body composition, and such studies focus on analyses of the entire diet, rather than on the intake of individual nutrients or food groups. An analysis of dietary patterns supports dietary assessments from a global perspective, and it favors the implementation of strategies that promote healthy eating habits and prevent nutrient-related diseases and conditions [5].

The statistical analysis confirmed that a nutrition model can influence body composition parameters. The healthy nutrition model was associated with a lower percentage of body fat $(\mathrm{p}<0.05 ; \mathrm{OR}=0.76$; $\mathrm{CI} 95$ : $0.34-1.01)$ and significantly lower visceral fat levels $(\mathrm{p}<0.01 ; \mathrm{OR}=0.67$; CI95: 0.31-0.89). Individuals with a healthy dietary pattern consumed raw vegetables / fruit significantly more frequently (once a day / several times a day) than the respondents belonging to the processed food model (who consumed vegetables several times a week and fruit once a day). According to several systematic reviews, a higher intake of vegetables and fruit may be an effective strategy to control weight $[1,30]$, and vegetables play a particularly important role in weight control [25]. The consumption of potatoes, vegetable and mixed fruit-vegetable juice did not differ across age groups or nutrition models. The consumption of potatoes was significantly less frequent (one to three times a month; $p=0.002$ ) and the consumption of vegetable juice was significantly more frequent (several times a week; $\mathrm{p}=0.001$ ) only in the group of women aged 18-39. According to some studies, frequent intake of potatoes, in particular French fries, is directly related with a higher BMI score [3]. In the presented study, women who ate potatoes one to three times a week had lower BMI scores than women who consumed potatoes several times a week and more often $(\mathrm{p}=0.003)$. Respondents belonging to the healthy nutrition model also consumed fermented dairy beverages such as yogurt, kefir and tvorog cheese significantly more often (several times a week/ once a day; $p=0.003$ ) than individuals belonging to the optimal nutrition model (several times a week) and the processed food model (1-3 three times per month)

Similarly to the study conducted by Torres-Costoso et al. [34], where less than daily intake of milk was correlated with a significantly higher BMI score $(p=0.006)$, the surveyed respondents who consumed milk and fermented dairy beverages at least once daily were characterized by lower BMI scores $(22.12 \mathrm{~kg} /$ $\mathrm{m} 2$ ) than those who ate dairy products several times a week or less often (BMI of $23.27 \mathrm{~kg} / \mathrm{m} 2 ; \mathrm{p}=0.003$ ). However, Chen et al. [6 ] demonstrated that dairy products, including yogurt, significantly contributed to weight loss, stabilization of BMI and a decrease in body fat percentage only when they were a part of a balanced diet with the appropriate energy content.

Whole grains are the key components of healthy eating patterns. Their low energy density and satiating effects are responsible for their potential role in weight control [11]. A meta-analysis of clinical trials conducted in 2013 revealed that whole grain consumption did not exert a significant effect on body weight [24]. According to Kristensen et al. [18] and Sadeghi et al. [28], the consumption of whole-grain products (according to dietary guidelines) did not influence the body fat percentage or fat-free mass. In the present study, the frequency of whole grain intake (barley groats, oat flakes, whole-grain pasta, other coarse groats, whole-grain bread) was not correlated with BMI and other body composition parameters $(p>0.05)$. However, individuals who ate white bread (wheat, rye or wheat-rye bread, toast bread) less than once daily were characterized by lower visceral fat levels $(\mathrm{p}>0.05)$. In turn, the consumption frequency of white rice, pasta and fine groats was not correlated with body composition parameters.

Individuals belonging to the processed food model were at significantly higher risk of overweight and obesity expressed by BMI scores $(\mathrm{OR}=1.55 ; 95 \% \mathrm{CI}$ : 1.26-1.99). The average BMI score was $28.19 \pm 3.45$ $\mathrm{kg} / \mathrm{m}^{2}$ in the processed food model, $23.78 \pm 2.21 \mathrm{~kg} /$ $\mathrm{m}^{2}$ in the control group, and $22.17 \pm 2.69 \mathrm{~kg} / \mathrm{m}^{2}$ in the healthy nutrition model. Responds belonging to the processed food model were also characterized by considerably higher body fat percentage $(\mathrm{OR}=1.89$, 95\%CI: 1.37-2.34) and higher visceral fat levels $(\mathrm{OR}=2.12$; 95\%CI: 1.42-2.34). Frequent intake (at least several times a week) of sweetened carbonated or non-carbonated beverages $(\mathrm{p}=0.002)$ and instant foods ( $p=0.006)$ were the main risk factors. Fast foods such as French fries, hamburgers and pizza which are energy dense and rich in saturated fatty acids and trans fats [16] significantly contributed to increase in the evaluated body composition parameters, in particular in men in all age groups $(\mathrm{p}=0.003)$ and in women aged 40-59 who consumed these products on a daily basis $(p=0.002)$. The association between frequent fast food intake and obesity was also demonstrated by Burgoine et al. (OR=1.51, 95\% CI: 1.40-1.64) and other studies [4, $7,23,26]$. A study of the Spanish population revealed that fast food consumption more than once a week increased the risk of obesity by $129 \%$ [29]. A study conducted in the USA demonstrated that individuals 
aged 18-39 who consumed fast food more than twice a week gained $4.5 \mathrm{~kg}$ over a period of 15 years and were characterized by higher visceral fat levels than subjects who consumed fast foods less than once a week [23].

\section{Strengths and limitations}

Unlike many nutrition studies which rely on BMI scores only, this study evaluated the dietary patterns of the examined population based on the results of a body composition analysis. The use of a portable body composition monitor enabled the researchers to reach a higher number of respondents. The validated KomPAN questionnaire was adapted to the Polish population aged 16-65, and it was used to assess the consumption of the most popular foods and beverages. The identified consumption frequencies were used to identify nutrition models that increase or decrease the risk of diet-dependent diseases, overweight and obesity.

The main limitation of the presented research was the high percentage of respondents who failed to prepare for the body composition analysis according to instructions. The percentage of respondents who did not complete the questionnaire correctly or did not answer all questions was also high. The influence of different types of physical activity and their duration on body composition was not analyzed. The inclusion criteria reduced the number of respondents potentially available for the trial; therefore, the results are limited to the subjects who participated in the study. Another possible limitation was that the phase of the menstrual cycle was not determined in female participants. The study did not account for the fact that the luteal phase is characterized by higher body mass and water retention, whereas the follicular phase is generally associated with the lowest body mass. In the future, these aspects should be considered when planning anthropometric measurements and body composition analyses. Despite these limitations, this is the first study to analyze the relationship between nutrition models and body composition in Polish adults. Further research involving a larger population sample is needed to validate the presented results.

\section{CONCLUSIONS}

This study demonstrated that dietary patterns and nutrition models can be associated with body composition parameters. The respondents belonging to the healthy nutrition model were characterized by lower body fat percentage and significantly lower visceral fat levels. In contrast, the participants belonging to the processed food model were characterized by higher BMI scores, higher body fat percentage and higher visceral fat levels, which indicates that the consumption of processed foods can contribute to overweight and obesity. Physical activity was not correlated with the physique rating. Higher levels of physical activity were not associated with lower BMI scores. However, further research is needed to determine the impact of exercise duration and quality on body composition parameters.

\section{Acknowledgments}

The authors would like to thank all participants who contributed to this study and assisted in body composition measurements: Kinga Tomporowska, Agnieszka Filipiak, Justyna Malec and Joanna Kostecka.

\section{Conflict of interest}

The authors declare no conflict of interest.

\section{REFERENCES}

1. Alinia S., Hels $O$., Tetens $I .:$ The potential association between fruit intake and body weight - a review. Obes Rev 2009; 10: 639-647. doi: 10.1111/j.1467789X.2009.00582.x

2. Berge J.M., Wall M., Larson N., Loth K.A., NeumarkSztainer D.: Family functioning: associations with weight status, eating behaviors, and physical activity in adolescents. J Adolesc Health 2013;52(3):351-357. https://doi.org/10.1016/j.jadohealth.2012.07.006

3. Borch D., Juul-Hindsgaul N., Veller M., Astrup A., Jaskolowski J., Raben A.: Potatoes and risk of obesity, type 2 diabetes, and cardiovascular disease in apparently healthy adults: a systematic review of clinical intervention and observational studies. Am J Clin Nutr 2016;104(2):489-498. doi: 10.3945/ajen.116.132332

4. Burgoine T., Sarkar C., Webster C.J., Monsivais $P .:$ Examining the interaction of fast-food outlet exposure and income on diet and obesity: evidence from 51,361 UK Biobank participants. Int J Behav Nutr Phys Act. 2018;15(1):71. doi: 10.1186/s12966-018-0699-8

5. Carvalho C.A., Fonsêca P.C.A., Nobre L.N., Priore S.E., Franceschini S.C.C.: Methods of a posteriori identification of food patterns in Brazilian children: a systematic review. Ciên Saúde Colet 2016;21(1):143154. doi: 10.1590/1413-81232015211.18962014

6. Chen M., Pan A., Malik V.S., Hu F.B.: Effects of dairy intake on body weight and fat: a meta-analysis of randomized controlled trials. Am J Clin Nutr 2012; 96(4):735-747. doi: https://doi.org/10.3945/ ajcn.112.037119

7. Duffey K.J., Gordon-Larsen P., Jacobs D.R. Jr., Williams O.D., Popkin B.M.: Differential associations of fast food and restaurant food consumption with 3-y change in body mass index: the Coronary Artery Risk Development in Young Adults Study. Am J Clin Nutr 2007;85(1):201-208. doi: 10.1093/ajen/85.1.201

8. Egg S., Erler J., Perktold B., Hasenegger V., Rust P., Ramoner R., König J., Purtscher A.E.: Traditional v. modern dietary patterns among a population in western 
Austria: associations with body composition and nutrient profile. Public Health Nutr 2019;22(3):455-465. doi:10.1017/S1368980018003270

9. Elffers T.W., de Mutsert R., Lamb H.J., de Roos A., Willems van Dijk K., Rosendaal F.R., Jukema J.W., Trompet $S$.: Body fat distribution, in particular visceral fat, is associated with cardiometabolic risk factors in obese women. PLoS One 2017;12(9):e0185403. doi: 10.1371/journal.pone.0185403.

10. Gawęcki J.: Kwestionariusz do badania poglądów i zwyczajów żywieniowych oraz procedura opracowywania wyników. Warszawa 2014, http://www. knozc.pan.pl/ doi: 10.13140/2.1.3207.7125

11. Giacco R., Della Pepa G., Luongo D., Riccardi G.: Whole grain intake in relation to body weight: From epidemiological evidence to clinical trials. Nutr Metab Cardiovasc Dis 2011;21:901-908. doi: 10.1016/j. numecd.2011.07.003

12. Global, regional, and national age-sex specific all-cause and cause-specific mortality for 240 causes of death, 1990-2013: a systematic analysis for the Global Burden of Disease Study 2013. GBD 2013 Mortality and Causes of Death Collaborators. Lancet 2015;385(9963):117-171. doi: http://dx.doi.org/10.1016/ S0140-6736(14)61682-2

13. Guh D.P., Zhang W., Bansback N., Amarsi D., Birmingham C.L., Anis H.A.: The incidence of co-morbidities related to obesity and overweight: A systematic review and meta-analysis. BMC Public Health 2009;9:88. doi:10.1186/1471-2458-9-88

14. Haq I.U., Mariyam Z., Zeb F., Jiang P., Wu X., Shah J., $X u$ C., Zhou M., Feng Q., Li M.: Identification of Body Composition, Dietary Patterns and Its Associated Factors in Medical University Students in China. Ecol Food Nutr 2020;59(1):65-78. doi: 10.1080/03670244.2019.1663350

15. Institute of Medicine (US) Subcommittee on Military Weight Management. Weight Management: State of the Science and Opportunities for Military Programs. Washington (DC): National Academies Press (US); 2004. 3, Factors That Influence Body Weight. Available from: https://www.ncbi.nlm.nih.gov/books/ NBK221834 doi: 10.17226/10783

16. Jaworowska A., Blackham T., Davies I.G., Stevenson $L .:$ Nutritional challenges and health implications of takeaway and fast food. Nutr Rev 2013;71(5):310-318. doi: https://doi.org/10.1111/nure.12031

17. Jayasinghe S.N., Breier B.H., McNaughton S.A., Russell A.P., Della Gatta P.A., Mason S., Stonehouse W., Walsh D.C.I., Kruger R.: Dietary Patterns in New Zealand Women: Evaluating Differences in Body Composition and Metabolic Biomarkers. Nutrients 2019;11(7):1643. doi: 10.3390/nu11071643

18. Kristensen M., Toubro S., Jensen M.G., Ross A.B., Riboldi G., Petronio M., Bügel S., Tetens I., Astrup A.: Whole grain compared with refined wheat decreases the percentage of body fat following a 12-week, energyrestricted dietary intervention in postmenopausal women. J Nutr 2012;142:710-716. doi: 10.3945/ jn. 111.142315

19. Lopez Y. III., O'Connor D.P., Ledoux T.A., Lee, R.E.: Analysis of body composition methods in a community sample of African American women. Women Health 2011;51:709-723. doi: 10.1080/03630242.2011.623222

20.Menke A., Muntner P., Wildman R.P., Reynolds K., He $J .:$ Measures of adiposity and cardiovascular disease risk factors. Obesity (Silver Spring) 2007;15(3):785795. doi: 10.1038/oby.2007.593

21. Moore S.C., Mayne S.T., Graubard B.I., Schatzkin A., Albanes D., Schairer C., Hoover R.N., Leitzmann M.F.: Past body mass index and risk of mortality among women. Int J Obes. (Lond) 2008; 32(5):730-739. doi: 10.1038/sj.ijo.0803801

22.Okorodudu D.O., Jumean M.F., Montori V.M., RomeroCorral A., Somers V.K., Erwin P.J., Lopez-Jimenez F.: Diagnostic performance of body mass index to identify obesity as defined by body adiposity: a systematic review and meta-analysis. Int J Obes. (Lond) 2010; 34:791-799. doi: 10.1038/ijo.2010.5

23.Pereira M.A., Kartashov A.I., Ebbeling C.B., Van Horn L., Slattery M.L., Jacobs D.R. Jr., Ludwig D.S.: Fast-food habits, weight gain, and insulin resistance (the CARDIA study): 15-year prospective analysis. Lancet 2005;365(9453):36-42. doi: 10.1016/S01406736(04)17663-0

24.Pol K., Christensen R., Bartels E.M., Raben A., Tetens I., Kristensen $M .:$ Whole grain and body weight changes in apparently healthy adults: a systematic review and metaanalysis of randomized controlled studies. Am J Clin Nutr 2013;98:872-884. doi: 10.3945/ajcn.113.064659

25.Rautiainen S., Wang L., Lee I.M., Manson J.A.E., Buring J.E., Sesso H.D.: Higher intake of fruit, but not vegetables or fiber, at baseline is associated with lower risk of becoming overweight or obese in middleaged and older women of normal BMI at baseline. J Nutr 2015;145:960-968. doi: 10.3945/jn.114.199158

26.Richardson A.S., Meyer K.A., Howard A.G., BooneHeinonen J., Popkin B.M., Evenson K.R., Shikany J.M., Lewis C.E., Gordon-Larsen P.: Multiple pathways from the neighborhood food environment to increased body mass index through dietary behaviors: A structural equation-based analysis in the CARDIA study. Health Place 2015; 36:74-87. doi: 10.1016/j. healthplace.2015.09.003

27. Russell J., Flood V., Rochtchina E., Gopinath B., Allman-Farinelli M., Bauman A., Mitchell P.: Adherence to dietary guidelines and 15-year risk of all-cause mortality. Br J Nutr 2013;109(3):547-555. doi: 10.1017/ S0007114512001377

28.SadeghiO., SadeghianM., RahmaniS., Maleki V., Larijani B., Esmaillzadeh A.: Whole-Grain Consumption Does Not Affect Obesity Measures: An Updated Systematic Review and Meta-analysis of Randomized Clinical Trials. Adv Nutr 2020;11(2):280-292. doi: https://oi. org/10.1093/advances/nmz076

29. Schröder H., Fïto M., Covas M.I.: REGICOR investigators. Association of fast food consumption with energy intake, diet quality, body mass index and the risk of obesity in a representative Mediterranean population. Br J Nutr 2007; 98(6):1274-1280. doi: $10.1017 / \mathrm{S} 0007114507781436$ 
30.Schwingshackl L., Hoffmann G., Kalle-Uhlmann T., Arregui M., Buijsse B., Boeing H.: Fruit and vegetable consumption and changes in anthropometric variables in adult populations: a systematic review and meta-analysis of prospective cohort studies. PLoS One 2015;10: e0140846. doi: 10.1371/journal.pone.0140846

31. Shuster A., Patlas M., Pinthus J.H., Mourtzakis M.: The clinical importance of visceral adiposity: a critical review of methods for visceral adipose tissue analysis. Br J Radiol 2012; 85(1009):1-10. doi: 10.1259/ $\mathrm{bjr} / 38447238$

32. Soltero S.M., Palacios C.: Association between dietary patterns and body composition in a group or Puerto Rican obese adults: a pilot study. P R Health Sci J 2011;30(1):22-27.

33. Togo P., Osler M., Sorensen T.I., Heitmann B.L.: A longitudinal study of food intake patterns and obesity in adult Danish men and women. Int J Obes Relat Metab Disord 2004; 28:583-593. doi: 10.1038/sj.ijo.0802598

34.Torres-Costoso A., López-Muñoz P., Ferri-Morales A., Bravo-Morales E., Martínez-Vizcaíno V., GarridoMiguel M.: Body Mass Index, Lean Mass, and Body Fat
Percentage as Mediators of the Relationship between Milk Consumption and Bone Health in Young Adults. Nutrients 2019; 11: 2500. doi: 10.3390/nu11102500

35. Wádołowska L.: Zasady obliczania i interpretacji wyników. W: Przewodnik metodyczny badań sposobu żywienia. red.: Gronowska-Senger A., Wyd. Komitetu Nauki o Żywieniu Człowieka Polskiej Akademii Nauk, Warszawa, 2013:38-67. doi: 10.13140/2.1.2748.9601

36. Wirfält E., Drake I., Wallström P.: What do review papers conclude about food and dietary patterns? Food Nutr Res 2013; 57: 20523. doi: 10.3402/fnr.v57i0.20523

37. Wirt A., Collins C.E.: Diet quality what is it and does it matter? Public Health Nutr 2009;12:2473-2492. doi: $10.1017 / \mathrm{S} 136898000900531 \mathrm{X}$

38. wwwl. Health Risks of Being Overweight www.niddk. nih.gov/health-information/weight -management/ health -risks-overweight.

Received: 07.01.2021

Accepted: 22.02.2021 